\title{
A importância das Redes Sociais como ferramenta de marketing para aumento de vantagem competitiva em uma IES de Juazeiro do Norte - CE
}

The importance of Social Networks as a marketing tool to increase competitive advantage in an IES in Juazeiro do Norte - CE

La importancia de las Redes Sociales como herramienta de marketing para incrementar la ventaja competitiva en una IES en Juazeiro do Norte - CE

\author{
Hommel Pinheiro Lima \\ ORCID: https://orcid.org/0000-0002-0174-0305 \\ Centro Universitário Paraiso, Brasil \\ E-mail: hommellimaa3@gmail.com \\ Jose Ermeson Silva Carmo \\ ORCID: https://orcid.org/0000-0002-0514-3735 \\ Centro Universitário Paraiso, Brasil \\ E-mail: ermeson.silva@fapce.edu.br \\ Maria Aparecida Feitosa Cândido Herculano \\ ORCID: https://orcid.org/0000-0002-5124-9258 \\ Centro Universitário Paraiso, Brasil \\ E-mail: cidinhacandido@gmail.com
}

\begin{abstract}
Resumo
As novas dinâmicas econômicas e comerciais do mundo globalizado impõem ao mercado empresarial em todo mundo uma série de mudanças e adaptações do empresário em busca de técnicas que possam não só acompanhar, mas, sobretudo fazer a diferença em um contexto comercial competitivo. Deste modo a internet e as chamadas mídias ou redes sociais tem sido um importante mercado despertando interesse dado as suas facilidades de interatividade com o consumidor revendo-se ultimamente um mercado potencial que já contém um grande número de investidores movimentando uma quantidade significativa de capital. O presente trabalho estuda o desenvolvimento do marketing digital nos últimos anos no Brasil e mais especificamente o seu desenvolvimento nas redes ou mídias sociais em uma IES - Instituição de Ensino Superior particular de Juazeiro do Norte - CE. Foi então utilizado um instrumento de pesquisa já feito por uma empresa e aplicado/adaptado em uma organização em uma IES a fim de identificar o trabalho feito com mídias sociais na empresa. Trata-se de uma pesquisa descritiva, que usou um estudo de caso. Foi feita entrevista com um funcionário da IES, encarregado pelo setor de atividades em TI responsável pelo monitoramento das redes. Foi verificado e apurado que a IES está no caminho certo em relação ao trabalho com as redes sociais, dedicando tempo e trabalhando com estratégias para o contato com o aluno, porém percebeu-se a necessidade de uma maior interação da TI com a área de Marketing e Comunicação da IES para juntos trabalharem a comunicação de forma eficiente e eficaz.
\end{abstract}

Palavras-chave: Redes sociais; Marketing digital; IES.

\begin{abstract}
The new economic and commercial dynamics of the globalized world impose on the business market all over the world a series of changes and adaptations by the beginner in search of techniques that not only accompany, but, above all, make a difference in a competitive commercial context. Thus, the internet and so-called media or social networks has been an important market, attracting interest, given its facilities for interacting with consumers, lately revising a potential market that already contains a large number of investors moving a small amount of capital. The present work studies the development of digital marketing in recent years in Brazil and more specifically its development in social networks or media in an IES - Private Higher Education Institution in Juazeiro do Norte - CE. It was then used a research instrument already done for a company and paid / adapted in an organization in an HEI in order to identify the work done with social media in the company. This is a descriptive research, which includes a case study. An interview was made with an IES employee, in charge of the IT activities sector responsible for monitoring the networks. It was verified and verified that the HEI is on the right path in relation to working with social networks, dedicating time and working with contact with the student, but avoiding the need for greater IT interaction with the Marketing and Communication area IES to work together to communicate efficiently and effectively.
\end{abstract}

Keywords: Social networks; Digital marketing; IES. 


\begin{abstract}
Resumen
Las nuevas dinámicas económicas y comerciales del mundo globalizado imponen en el mercado empresarial mundial una serie de cambios y adaptaciones por parte del emprendedor en busca de técnicas que no solo puedan acompañar, sino, sobre todo, marcar la diferencia en un contexto comercial competitivo. De esta forma, internet y los llamados medios o redes sociales han sido un mercado importante, despertando interés dadas sus facilidades para interactuar con los consumidores, revisando últimamente un mercado potencial que ya contiene una gran cantidad de inversores moviendo una importante cantidad de capital. El presente trabajo estudia el desarrollo del marketing digital en los últimos años en Brasil y más específicamente su desarrollo en redes sociales o medios de comunicación en una IES Institución Privada de Educación Superior en Juazeiro do Norte - CE. Luego se utilizó un instrumento de investigación ya realizado. por una empresa y aplicado / adaptado en una organización en una IES con el fin de identificar el trabajo realizado con las redes sociales en la empresa. Es una investigación descriptiva, que utilizó un estudio de caso. Se realizó una entrevista con un empleado de IES, a cargo del sector de actividades de TI responsable de monitorear las redes. Se constató y constató que la IES va por buen camino en relación al trabajo con las redes sociales, dedicando tiempo y trabajando con estrategias de contacto con el alumno, pero se concretó la necesidad de una mayor interacción entre TI y el área de Marketing. y Comunicación de la IES para trabajar juntos para comunicarse de manera eficiente y efectiva. Palabras clave: Redes sociales; Marketing digital; IES.
\end{abstract}

\title{
1. Introdução
}

Embora o desenvolvimento do marketing tenha se dado gradualmente, como comumente ocorreu em todas as áreas do conhecimento, somente a partir da década de 2000 com a popularização do uso da internet é que surgem as primeiras pesquisas e publicações sobre web marketing. A partir daí o desenvolvimento do chamado comércio eletrônico passa a chamar atenção por sua facilidade e baixo custo para os empresários que com o uso da nova ferramenta podem estar disponíveis virtualmente para o mundo inteiro. Santos (2019) estabelece a esta nova era o conceito de "técnico-científico-informacional", onde o desenvolvimento econômico não se trata mais de quem tem maior espaço físico ocupado, mas, sobretudo quem tem o maior número de informações a ser usada de modo eficientemente válido dentre as novas formas de competitividade.

O que se torna importante destacar é que estas novas formas de competitividade favorecem também pequenas empresas em virtude da possibilidade de investimento de baixo custo colocando assim os pequenos empresários em um mercado que até bem pouco tempo era desconhecido por eles. O recente desenvolvimento das chamadas "redes sociais" deu a internet um novo conceito de comércio virtual, uma vez que o empreendimento agora se dá por meio da venda de produtos e serviços usando o diferencial do buzzmarketing e do marketing viral, onde o empreendedor muitas vezes já não mais investe no desenvolvimento de um grande site, usando por vezes tão somente a propagação viral de seus produtos, preços e endereço físico.

Como foi dito acima, a necessidade de adaptação do mercado e o empreendimento de novas estratégias de venda vêm dando aos empreendimentos virtuais grande importância ao que antes eram investidos em empresas espalhadas pelo mundo. Estas que outrora ocupavam espaço físico consumiam recursos em grande soma e grande número de empregados, agora se mostram com outro perfil Torres, (2019). Os consumidores em foco agora têm novos hábitos, exigindo praticidade, conforto e eficiência colocando os novos empresários frente a uma realidade que necessitam adaptarem-se a suas demandas, as novas tecnologias, ao mundo virtual e especificamente, ao aproveitamento das redes sociais como ferramenta de marketing.

Diante do exposto acima, torna-se imprescindível que todas as organizações atuais busquem maneiras atuais de se relacionarem com seus públicos, e para uma IES - Instituição de Ensino Superior, não poderia ser diferente. É importante que tais órgãos planejem e executem eficientes comunicações em redes sociais para não só divulgar e sim monitorar o que ocorre em tais redes. Esse monitoramento torna-se importante ao ponto de a IES poder sempre interagir com seu público, os alunos, e ao mesmo tempo poder rapidamente se proteger de alguma publicação nociva à imagem da instituição.

Para tanto, o presente trabalho tem como problemática: Como uma administração de redes sociais ajuda no desenvolvimento de vantagem competitiva para uma IES - em Juazeiro do Norte-CE?

Como objetivo geral, tem-se: Analisar a administração de redes sociais em uma IES na cidade de Juazeiro do Norte-CE. 
Para se chegar ao objetivo geral, foram elencados os seguintes objetivos específicos:

1. Descrever a atividade de administração de redes sociais da IES;

2. Identificar os principais benefícios oriundos da administração de redes sociais para a IES;

3. Propor ações de melhorias com base no que foi encontrado na pesquisa.

A partir do presente trabalho buscando desenvolver um estudo e levantamento sobre o desenvolvimento do marketing e seu uso nas redes sociais observa-se a necessidade de pré-estabelecer um referencial teórico válido onde o mesmo possa embasar suficientemente a pesquisa dando a mesma a maior objetividade e expressão sobre a realidade estudada.

Deste modo, entre os autores estudados utilizou-se primeiramente o conceito de marketing de Richers (2019) citado por Nanni e Cañete onde diz: "marketing como sendo as atividades sistemáticas de uma organização humana voltada à busca e realização de trocas para com o seu meio ambiente, visando benefícios específicos". De posse do conceito acima citado ressaltase para a necessidade de perceber que uma nova realidade se impõe sobre o mesmo, uma vez que com o desenvolvimento da internet, em relação ao que antes se chamava de território, ou espaço vivido Lafebvre (1974) ocupado fisicamente onde se exercia o poder. Um conjunto de signos e significados agora deve ser somado à expressão em um ambiente virtual, embora não ocupando mais um espaço físico, por isso constata-se uma nova forma de exercício territorial-comercial onde as leis de mercado, a concorrência, a busca por melhores ofertas de serviços, preços e clientes se especializam e tornam-se reais no comércio virtual.

Por sua vez, Cardozo (2018) define rede social como um conjunto de participantes autônomos, reunidos em um espaço virtual com o intuito de compartilhar ideias, recursos e afinidades em comum. Normalmente as redes sociais são de acesso gratuito onde a pluralidade de assuntos é uma de suas características, de modo que, também haja a possibilidade de que alguns usuários possam se estabelecer em determinadas redes de assuntos mais específicos tais como Ebah (Rede social destinada a estudantes universitários no Brasil), Flickr (Rede Social com o objetivo de compartilhar fotografias), GoPets (bichos de estimação), etc.

Segundo o autor supracitado, outro ponto que merece destaque é que as redes sociais, ao contrário da estrutura dos antigos portais (Terra, UOL, BOL) têm uma característica diferente de interação. Não se trata mais de uma grande estrutura que fornece informações e corresponde a ação do internauta que de certo modo "consome" o conteúdo propiciado pelo site. É fundamental perceber que houve nos últimos anos uma clivagem em relação ao modo com que os novos usuários utilizam a internet. Agora é necessário que os empresários abram espaço para que o que antes era um mero consumidor passivo também possa formular e espalhar seu próprio conteúdo. Portanto um dos méritos das chamadas comunidades virtuais é também a abertura para uma troca de informações onde se formula um relacionamento de confiança, de interesses afins, uma vez que, como já foi dito, as comunidades se particularizam por assuntos e temas específicos, fantasia e transação.

Para o presente trabalho é necessário que fique claro a distinção entre os conceitos de marketing e rede sociais explicitados acima e, sobretudo o entendimento que no atual E-commerce eles atuam em conjunto. Percebendo que as redes sociais nada mais são do que a extensão de uma série de comportamento e necessidades humanas tais como a necessidade de viver em conjunto, em sentir-se acolhido e ter suas ideias recepcionadas, não descartando a realidade que as mesmas possam ser bem aceitas ou não, enfatizamos que o que há de novo é o uso das ferramentas tecnológicas atualmente disponíveis para satisfazer desejos humanos tão antigos quanto a própria humanidade bem como sua característica de ser um animal político ZoonPolitikon, Aristóteles (1999).

Neste contexto, Spitz (2017) nos diz que não basta o cidadão saber ler ou escrever, ou, por meio de alguma formação técnica ou acadêmica ter desenvolvido alguma profissão específica. Com a dinâmica da era técnico-científico-informacional o cidadão do século XXI tem que estar devidamente informado, não mais apenas sobre aspectos de interesse de sua informação, mas através da internet poder consultar sobre os melhores preços dos supermercados, promoções sobre produtos tecnológicos, 
lançamentos, previsão do tempo, trânsito, bolsa de valores, exposições e uma série de outras benesses que outrora um cidadão comum jamais pensaria que lhe estaria disponível.

\section{Marketing viral e redes sociais}

Ao se estudar as demais formas de comunicação onde o marketing primeiramente se desenvolveu com a televisão e o rádio entre outras formas, pode-se perceber que com elas o empresário tinha uma comunicação de mão única onde o anúncio expunha ao possível cliente uma marca ou produto onde o mesmo era simplesmente consumido/adquirido ou descartado, sem uma maior troca de informações entre o empresário e o consumidor.

Ainda sobre tais tecnologias Qualman (2019) fala que: “Anúncios de televisão milionários não são mais o centro dos influenciadores na intenção de compra". Logo após este período várias empresas desenvolveram e aderiram à implantação do SAC (Serviço de Atendimento ao Consumidor) em suas empresas. Invariavelmente a maior parte destes atendimentos era insuficiente e não satisfaziam plenamente o consumidor.

Nessa época já havia sido desenvolvido as primeiras técnicas de pesquisa de mercado, onde empresários e investidores estudavam determinados setores econômicos para que após isso pudessem investir ou não nos mesmos. $\mathrm{O}$ que se insiste aqui, porém, é que tais estudos mesmo sendo desenvolvidos em técnicas atuais de pesquisas elaboradas por agências de marketing e publicidade migrou em boa parte para o comércio eletrônico, onde este, por sua vez, dentre seus principais atrativos é a interatividade entre as marcas e seus clientes, particularizando suas ofertas de acordo com cada contexto, bem como, adaptandose a novas realidades. Sobre este aspecto vale lembrar mais uma vez Qualman (2019), que diz que "Pessoas fazendo referências a produtos e serviços por meio de ferramentas de mídias sociais são o novo rei” [...] "É o maior programa de referencias da história".

Porém, cabe aqui dizer que um dos principais feitos das redes sociais que são a intensa troca de informações e a rapidez de um feedback entre marcas/empresas e usuários e que atualmente conceituamos como marketing viral, não é algo tão novo. O conhecido boca a boca, a entrega de santinhos como recomendação de repassar para sete de seus amigos, por exemplo, são as primeiras formas de propagação viral. Raciocinando de um modo mais matemático, esta forma de propagação se dá em escala geométrica, uma vez que cada indivíduo/consumidor que entra em contato com o produto o propaga de forma espontânea para um número de pessoas bem maior, elevando-o para uma escala exponencial. Deste modo, usa-se aqui o conceito de marketing viral definido pela M2brnet quando afirma: "O Marketing Viral é a disseminação de uma informação de forma espontânea onde o próprio público que recebe a mensagem se encarrega de enviar para sua lista de contatos e assim por diante, tal qual um vírus. A grande vantagem é o custo baixo comparado com as outras formas de publicidade on-line".

Com o desenvolvimento da internet o conceito de marketing viral tomou proporções enormes. Entre os principais atrativos para a disseminação em forma viral está uma série de benefícios que o consumidor quer aproveitar e que as empresas já entenderam. Entre elas destacamos a possibilidade de desenvolver um e-mail gratuito onde a partir dele podemos trocar mensagens com outros usuários. É por ele que diversas empresas chegam aos consumidores e além de ser por ele que qualquer usuário pode fazer seu cadastro em alguma rede social.

Empresas de programas de software comumente oferecem programas chamados triais, onde o seu futuro cliente tem disponível por trinta dias uma versão mais simplificada do produto. A partir dessa vantagem tenta-se estimular o consumo e fazer com que aquele que entra em contato com aversão Trial, não só compre o produto, mas também repasse o benefício por ele aproveitado.

O que cabe aqui refletir é de qual modo pode-se usar os benefícios do marketing viral e das redes ou mídias sociais. Cabe aqui lembrar que a formação das redes sociais é a iniciativa própria dos usuários em compartilhar fotos, vídeos e demais interesses em um espaço virtual possivelmente localizado através de endereços de fácil acesso. Deste modo desenvolveram-se 
na internet redes que configuram os mais plurais interesses de usuários onde os mesmos movimentam milhões em um mercado ainda recente. Entre as mais populares estão:

1. Facebook,

2. MySpace,

3. Twitter,

4. Flixster,

5. Linkedin,

6. Tagged,

7. Classmates,

8. My Year Book,

9. Live Journal,

10. Imeem, entre outras.

A empresa Sophia Mind, especialista em pesquisa e inteligência em marketing feminino, em uma pesquisa feita em agosto de 2019 com 341 mulheres entre 18 e 60 anos usuárias da rede social com mais usuários no mundo, o Facebook, mostram os seguintes dados:

Gráfico 1: Utilização de redes sociais.

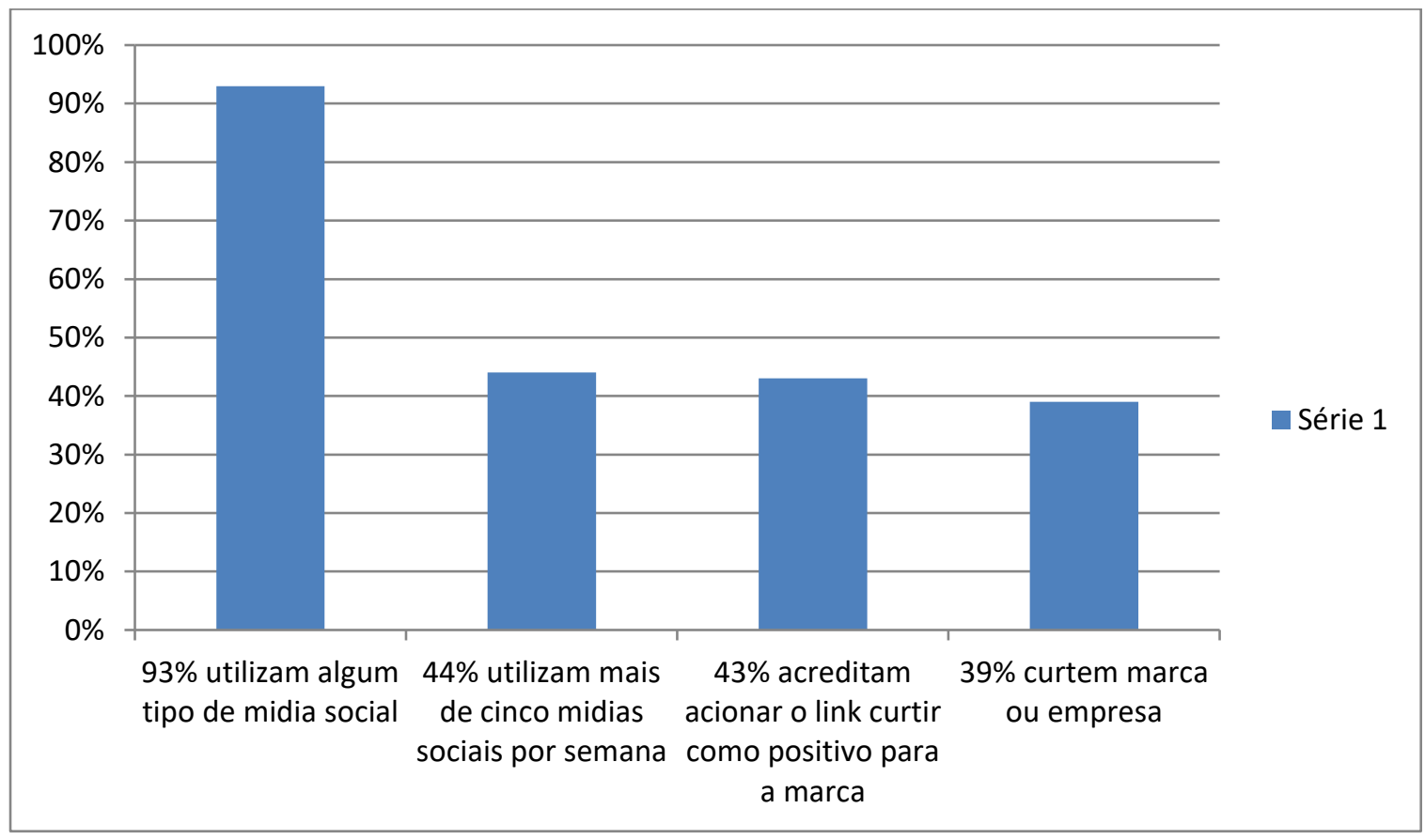

Fonte: Sophia Mind (adaptado pelos autores).

Observa-se que os dados acima confirmam que, embora a pesquisa seja feita com um público específico (mulheres entre 18 e 60 anos) o sucesso que a rede social tem no país fica claro e indiscutível. De modo mais direcionado, buscando entender a relação entre as usuárias com as marcas pode obter ainda mais dados que ajudam a delinear o perfil destas usuárias.

Elas por sua vez, ainda sobre o Facebook, buscam: 
Gráfico 2: Intenção com a utilização de redes sociais.

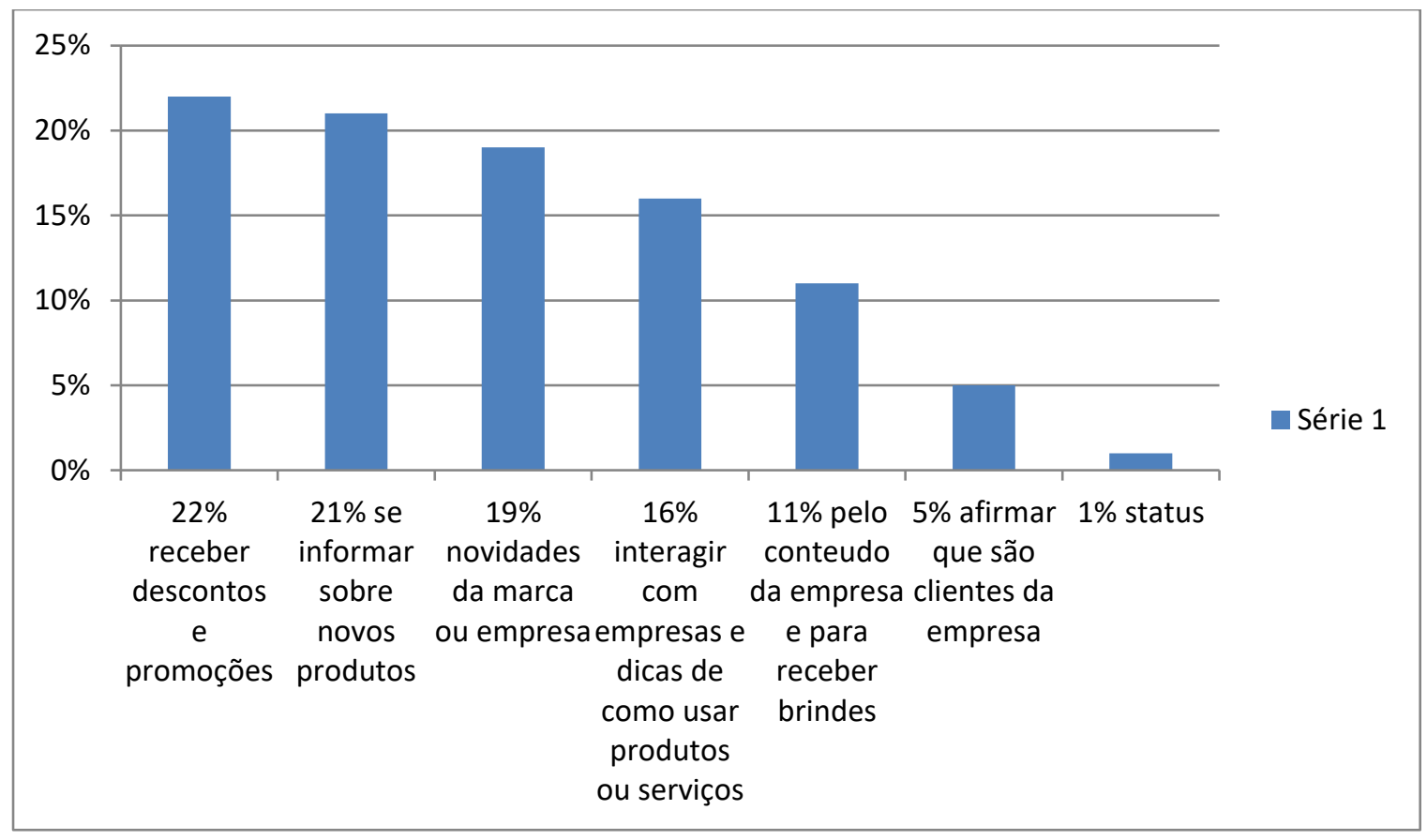

Fonte: Sophia Mind (adaptado pelos autores 2019).

Esse dado reflete obviamente a principal lei econômica que é adquirir a maior quantidade de produtos e serviços possíveis gastando a menor quantidade de seus recursos. Pode-se concluir que, o que se prevalece de fato é a tentativa de adquirir um bom produto por menor preço. Porém, é importante afirmar que a interatividade com a empresa é um adicional que pode fazer a diferença, onde se destaca quem melhor atende seus clientes.

\section{Grandes e pequenos empreendimentos nas redes sociais}

Atualmente as maiores empresas do mercado estão também entre as maiores dentro da internet e das mídias sociais. Destaca-se quem consegue não só oferecer um bom produto como manter a dinâmica das redes sociais que é sua interatividade. Ao se referir sobre o mercado nas redes/mídias sociais é válido destacar que assim como uma empresa ou marca tem ampla possibilidade de divulgar sua marca, a velocidade dessa propagação pode ter uma dualidade, uma vez que um cliente insatisfeito tem o mesmo poder de espalhar sua insatisfação para toda a sua rede de contatos com a mesma facilidade, podendo assim causar danos, muitas vezes, irreparáveis à marca.

Muitas empresas inseridas nas redes sociais desenvolvem nas mesmas um sistema de informação buscando adequar-se a realidade daquele território virtual que consiste em praticidade, velocidade, descontração e interação. A partir do momento que algum cliente precise de maiores informações ou fazer alguma reclamação, normalmente são atendidos na própria rede social em uso e não mais direcionados aos sites das devidas empresas onde lá se desenvolve um processo de atendimento bem mais lento, causando insatisfação.

Segundo a revista Exame, a empresa ForresterResearch desenvolveu uma pesquisa afirmando que até 2019 os investimentos em marketing online chegarão perto de US\$ 55 bilhões. Este montante representa ainda, apenas $21 \%$ do todo que é investido em marketing, de modo que há uma tendência em aumentar essa quantia que já é bem expressiva. O que se destaca nessa pesquisa é que o crescimento dos investimentos em mídias sociais tem uma taxa de $34 \%$ ao ano, sendo bem superior a qualquer outra possibilidade online. 
Entre as empresas destacadas entre as maiores FanPages no Facebook segundo a mesma revista destacam-se Peixe Urbano, L’Óreal Paris Brasil, Nike Futebol, Guaraná Antártica, Privalia Brasil, Oral-B Brasil, Gol Linhas Aéreas Inteligentes, Smirnoff Brasil, Azul Linhas Aéreas Brasileiras e Sony Music Brasil. As marcas mundiais, portanto, as mais globalizadas que destacam-se em um contexto mais amplo estão a Coca-Cola, Starbucks, Dell, Dunkin' Donuts, JetBlue e The History Channel.

Cabe aqui acrescentar o que não foi levantado por estas pesquisas é que, neste mercado uma série de empresas e marcas até então desconhecidas ganham destaque pela qualidade de produtos oferecidos e, sobretudo pelo caráter inovador que as mesmas empreendem. Não podemos esquecer que o próprio Facebook é o exemplo de uma delas que foi desenvolvida por alguns estudantes e que tomou uma proporção até então inimaginável por seus criadores. Mais uma vez, sobre este fenômeno Qualman (2019) fala: "Os vencedores de hoje não são o resultado de uma elite de sangue azul ou de distribuidores monopolistas".

Segundo Shih (2019) outra especialista no assunto, escreveu em sua obra "The Facebook Era", que há sim grandes oportunidades de pequenas empresas se destacarem em mídias sociais, sobretudo no Facebook que é a mais utilizada atualmente. A ideia de ter uma propagação de seus produtos via internet com baixo custo tem sido um dos grandes atrativos para pequenas empresas em todo o mundo. Além disso, a facilidade de poder escolher clientes para onde o marketing será direcionado, selecionando-os por sexo, idade, comunidades e grupos determinados ajuda a economizar muito dinheiro em um empreendimento de marketing que, embora normalmente não seja aleatório, pois há estudos que também o fazem direcionados em outros veículos de informação, eles atualmente não estão tão em voga como as redes sociais.

A autora supracitada ressalta também o cuidado que as empresas devem ter ao fazer tal empreendimento. Assim como fora da internet, há uma série de pré-requisitos para que as empresas possam se utilizar do marketing de forma eficiente e que tais campanhas alcancem algum sucesso. A confiabilidade do cliente se dá a partir da qualidade de produtos juntamente com bons preços, bom atendimento e disposição da empresa em superar possíveis reclamações e insatisfações. Assim, há um bom número de empresas que por não terem uma organização prévia em sua estrutura, falhando em diversos pontos como: logística ineficiente, falta de treinamento em atendimento ao cliente, perca de foco, uso de mesma margem de lucro para vários produtos, entre tantas outras, vem fazendo com que diversas empresas que tinha potencial, acabem falhando, uma vez que o marketing exige que o empreendimento acompanhe o que foi divulgado e atenda as necessidades do consumidor.

As estratégias a serem adotadas variam imensamente, porém, há também uma série de semelhanças entre pequenas e grandes empresas. Entre eles está em pesquisar páginas de empresas e seus perfis nas redes sociais. A partir disso pode-se chegar a um denominador comum e fazer uso de muitos dados importantes. $\mathrm{O}$ custo de uma pesquisa dessa natureza é baixo estando acessível para quase todo pequeno empreendedor. Saber a cultura e as preferências de possíveis clientes não só darão um foco a ser direcionado ao produto, mas também a adequação e inovação da marca que está sendo veiculada, adaptando-se a ela as leis de mercado.

Entre as principais referências no marketing digital está Adolpho (2018) onde informa:

A campanha pode mudar em tempo real e com isso aumentar a taxa de conversão de uma hora para outra. Se a rede é mutante muda a cada segundo, você e sua empresa tem que mudar com ela. (...). Após a crise de 2008, as empresas não querem mais saber de perder dinheiro. A minimização do risco passa a ser uma exigência de toda a diretoria. Minimizar os riscos significa controlar cada processo de perto.

\section{Metodologia}

Para o trabalho proposto, utilizou-se o método de pesquisa qualitativa destinada ao público alvo e aos empresários, pois é um método de pesquisa social que utiliza técnicas estatísticas, assim realizando questionários e entrevistas, objetivando estes de que se tenham o retorno esperado. Deverão ser analisados alguns aspectos:

- Realizar entrevista com os funcionários da empresa que utiliza da ferramenta (redes sociais); 
- Identificar público alvo e suas preferências através das informações obtidas através da aplicação do questionário;

- Coletar os dados obtidos no questionário para análise e discussão dos mesmos no comparativo com o objetivo desejado;

- Processar os dados em planilha de Excel;

- Analisar os resultados;

- Divulgar os resultados obtidos através dos resultados obtidos na pesquisa.

Utilizou-se também no trabalho uma série de dados desenvolvidos por revistas e empresas que estudam e buscam entender o que se passa no cenário econômico mundial e do país na tentativa de perceber os mais novos investimentos do comércio eletrônico que investiram em pesquisas sobre o comércio nas redes sociais, a quantidade de horas gastas e quais redes mais utilizadas, as maiores empresas que lá investem e por fim, após a utilização de todo esse escopo, traçar um perfil sobre seus usuários que também serão seus possíveis clientes.

Para atender aos objetivos foi realizada um método de análise da problemática do desenvolvimento do marketing nas redes sócias, através do programa excel. Para tanto o método aplicado na pesquisa foi o levantamento e estudo bibliográfico acerca do objeto de estudo, a partir do mesmo possibilitou-se entender os pressupostos básicos do problema de uma forma geral. Após isso, desenvolveu-se a chamada pesquisa de campo, ou Ex-Post-Facto, onde se caracteriza por investigar as relações de causa e efeito do problema em questão buscando entender assim os principais fatores que propiciaram o desenvolvimento comercial nesta modalidade de espaço virtual (as redes sociais). A aplicação do presente método torna-se necessário uma vez que o problema estudado é um fato já ocorrido, cabendo-se, portanto, a pesquisa para a confirmação do mesmo com dados mais objetivos que virão a dar clareza sobre o fenômeno estudado.

O levantamento de dados também se mostrou necessário ao longo da pesquisa, e aqui buscou-se coletar os dados mais atuais por meio não só das referências bibliográficas, mas também por meio de sites que fornecem as últimas pesquisas sobre o assunto.

Nos dias 9 e 10 de março de 2019, durante a realização do Cariri Marketing Digital houve uma pesquisa com os participantes que analisou os seguintes aspectos:

- Os benefícios,

- Uso das redes sociais,

- Quais interesses e buscas de empresa e pessoas nas redes sociais,

- Como o usuário se comporta com os novos meios de comunicação.

Esta pesquisa dará um norte para os investimentos de empresas que pretendem investir nas redes sociais, mas não sabe de fato, se seu público alvo está nela. Nesta pesquisa foram feitas as seguintes perguntas:

- Quais os benefícios que você busca nas redes sociais?

- Quais os benefícios que não eram atendidos de maneira satisfatória nas redes sociais?

- Quais as redes sociais que você está cadastrado?

- Nas redes sociais, quais as redes que dedica maior parte do tempo?

- Quanto do seu tempo é dedicado às redes sociais numa base semanal?

- Onde mais acessa suas redes sociais?

- Quais fazem parte dos objetivos da sua empresa com a presença nas redes sociais.

- Qual área da empresa é responsável pela gestão da empresa nas redes sociais?

- Quais os objetivos/expectativas dos entrevistados ao se relacionar com empresas por meio de redes sociais? 


\section{Resultados}

Com base na pesquisa feita pela empresa Marketing Digital Cariri, informada acima, foi realizada uma entrevista em uma IES - Instituição de Ensino Superior com o intuito de conferir se a instituição utiliza as redes sociais como ferramenta de marketing e como faz tal trabalho. Abaixo seguem os quadros com as perguntas e respostas dos gestores e funcionários da IES responsável por trabalhar com tais ferramentas.

Quadro 1: Benefício das redes sociais:

\begin{tabular}{|c|c|c|c|c|}
\hline $\begin{array}{l}\text { Quais os benefícios que sua empresa busca nas redes } \\
\text { sociais? }\end{array}$ & $\begin{array}{c}\text { Não } \\
\text { considero }\end{array}$ & $\begin{array}{l}\text { Considero } \\
\text { pouco }\end{array}$ & $\begin{array}{l}\text { Considero } \\
\text { muito }\end{array}$ & $\begin{array}{l}\text { Considero } \\
\text { fundamental }\end{array}$ \\
\hline a.) Buscar e manter contatos profissionais & & & & $\mathbf{X}$ \\
\hline b.) Buscar e manter contatos pessoais & & & & $\mathbf{X}$ \\
\hline c.) Participar de fóruns, grupos ou fanpage & & & & $\mathbf{X}$ \\
\hline d.) Informação em tempo real dos seguidores & & & & $\mathbf{X}$ \\
\hline
\end{tabular}

Fonte: dados da pesquisa. (2019).

Com base nas respostas à pergunta sobre os benefícios que a empresa busca nas redes sociais, foi identificado que em todos os itens foi considerado como fundamental, ou seja, nos dias atuais, buscar e manter contatos profissionais, buscar e manter contatos pessoais, participar de fóruns e grupos e ter informação em tempo real dos seguidores são de fundamental importância para uma boa gestão das redes sociais.

Quadro 2: Benefícios que não eram atendidos satisfatoriamente nas redes sociais.

\begin{tabular}{|c|c|c|c|c|}
\hline & \multicolumn{4}{|c|}{ Escala } \\
\hline $\begin{array}{l}\text { Quais os benefícios que não eram atendidos de maneira } \\
\text { satisfatória nas redes sociais? }\end{array}$ & $\begin{array}{c}\text { Não } \\
\text { considero }\end{array}$ & $\begin{array}{l}\text { Considero } \\
\text { pouco }\end{array}$ & $\begin{array}{l}\text { Considero } \\
\text { muito }\end{array}$ & $\begin{array}{l}\text { Considero } \\
\text { fundamental }\end{array}$ \\
\hline a.) Desenvolver negócios para minha empresa & & & $\mathbf{X}$ & \\
\hline b.) Encontrar eventos online & & & $\mathbf{X}$ & \\
\hline c.) Entretenimento/lazer & & & $\mathbf{X}$ & \\
\hline d.) Buscar e manter contatos & & & & $\mathbf{X}$ \\
\hline
\end{tabular}

Fonte: Dados da pesquisa. (2019).

Com as informações sobre essas perguntas, respondidas por gestores e funcionários da IES, verificou-se que antes não era atendido o desenvolvimento de negócios, bem como encontrar eventos online e entretenimento e lazer, já a busca para contatos era a que mais não era atendida com a utilização das redes. Atualmente, com um trabalho mais profissional de monitoramento, as coisas vêm mudando e tudo é feito de forma a ser atendido pelas redes sociais, trabalhando a ferramenta em prol da organização. 
Quadro 3: Redes sociais cadastradas.

\begin{tabular}{|c|}
\hline Quais as redes sociais que você está cadastrado? \\
\hline Facebook \\
\hline Twitter \\
\hline Orkut \\
\hline Youtube \\
\hline Flickr \\
\hline Linkedin \\
\hline
\end{tabular}

Fonte: Dados da pesquisa. (2019).

Segundo informações do gestor da área, todas as opções foram preenchidas, isso quer dizer que o trabalho com redes sociais é tão importante que a empresa não pode negligenciar com nenhuma das opções. Todas devem fazer parte do acompanhamento e análises constantes de tais redes.

Quadro 4: Dedicação do tempo x Rede social:

\begin{tabular}{|c|}
\hline Quais as redes que dedica maior parte do tempo? \\
\hline $1^{\circ}$ lugar: Facebook \\
\hline $2^{\circ}$ lugar: Twitter \\
\hline $3^{\circ}$ lugar: Youtube \\
\hline $4^{\circ}$ lugar: Linkedin \\
\hline $5^{\circ}$ lugar: Flickr \\
\hline $6^{\circ}$ lugar: Orkut \\
\hline
\end{tabular}

Fonte: Dados da pesquisa. (2019).

Verifica-se que a rede mais utilizada, ou seja, a maior parte do tempo de dedicação por parte da gestão é a rede Facebook, realmente a mais utilizada no mundo. Isso reforça a pesquisa, informada no trabalho, feita pela empresa Sophia Mind, especialista em pesquisa e inteligência em marketing feminino, que em pesquisa feita em agosto de 2019 com 341 mulheres, realizaram estudos sobre redes sociais com base na utilização do Facebook, informando ser a mais utilizada por internautas e por isso a importância do estudo com essa rede.

Quadro 5: Dedicação as redes por semana:

\begin{tabular}{|l|}
\hline $\begin{array}{l}\text { Quanto do seu tempo é dedicado às redes sociais numa base } \\
\text { semanal? }\end{array}$ \\
\hline (X ) De doze a vinte horas \\
\hline ( ) De quatro a oito horas \\
\hline ( ) De uma hora a duas horas \\
\hline ( ) De meia hora a uma hora \\
\hline ( ) Menos de meia hora \\
\hline
\end{tabular}

Fonte: Dados da pesquisa. (2019).

Com a pergunta, verificou-se que semanalmente é dedicado de 12 a 20 horas para o monitoramento. Levando-se em conta uma carga horária de 44 horas semanais de trabalho, isso corresponde a mais ou menos de $27 \%$ a $45 \%$ do tempo disponível por semana para tal monitoramento, um tempo bastante razoável para o trato com as redes sociais. Tempo suficiente para o 
acompanhamento e caso ocorra algum problema, como citado no corpo do trabalho, sobre informações que denigram a imagem ou marca da empresa, os profissionais da IES poderem reverter a situação da forma que for mais adequada.

Quadro 6: Local de acesso às redes sociais:

\begin{tabular}{|l|}
\hline Onde mais acessa suas redes sociais? \\
\hline ( $\quad$ Casa \\
\hline ( X ) Trabalho/casa \\
\hline ( $\quad$ Trabalho \\
\hline ( $\quad$ Lan house \\
\hline
\end{tabular}

Fonte: Dados da pesquisa. (2019).

Sobre o quesito local de acesso, o gestor respondeu que acessa do trabalho e de casa, isso reforça a questão da quantidade de horas semanais dedicadas às redes, por se tratar de algo importante, o monitoramento pode ser feito não só pela empresa, mas sim por casa. É só conectar a internet, acessar a rede específica, ou redes específicas e monitorar. Melhorando a eficiência do monitoramento.

Quadro 7: Objetivo com a utilização das redes sociais:

\begin{tabular}{|c|c|c|c|c|}
\hline & \multicolumn{4}{|c|}{ Escala } \\
\hline $\begin{array}{l}\text { Quais dos itens abaixo fazem parte dos objetivos da sua } \\
\text { empresa com a utilização das redes sociais. }\end{array}$ & $\begin{array}{c}\text { Não } \\
\text { considero }\end{array}$ & $\begin{array}{l}\text { Considero } \\
\text { muito }\end{array}$ & $\begin{array}{l}\text { Considero } \\
\text { pouco }\end{array}$ & $\begin{array}{l}\text { Considero } \\
\text { fundamental }\end{array}$ \\
\hline Melhorar a relação com os clientes & & & & $\mathbf{X}$ \\
\hline Melhorar a comunicação da empresa & $\mathbf{X}$ & & & \\
\hline Se posicionar melhor no futuro & & $\mathbf{X}$ & & \\
\hline Melhorar a relação da empresa c/ fornecedores & & & & $\mathbf{X}$ \\
\hline
\end{tabular}

Fonte: Dados da pesquisa. (2019).

Sobre a indagação do objetivo da empresa com a utilização das redes sociais, foi verificado que é considerada fundamental a "melhoria da relação com os clientes", no caso aqui os alunos da IES, e a "melhoria da relação empresa com fornecedores" e foi considerado muito importante a questão de se posicionar melhor no futuro.

Um dado que chamou a atenção foi a não consideração para o item "melhorar a comunicação da empresa". Em se tratado de um veículo de extrema potencialidade de comunicação, esse item deve ser repensado, pois como foi informado pela empresa M2brnet, comentado nas referências do trabalho, em que diz que o Marketing Viral é a propagação de uma informação de forma espontânea onde o próprio público que recebe a mensagem se encarrega de enviar para sua lista de contatos e assim por diante, como se fosse um vírus, torna-se importante isso como uma vantagem enorme para a empresa e de baixo custo baixo, e logo, é fundamental que a IES saiba e melhore a comunicação aproveitando os "virais" que um membro da rede pode repassar para os demais. 
Quadro 8: Área responsável pela gestão das redes sociais:

\begin{tabular}{|l|}
\hline Qual área da empresa é responsável pela gestão nas redes sociais? \\
\hline ( ) Marketing/Comunicação \\
\hline ( X ) Tecnologia - TI \\
\hline ( ) Comercial \\
\hline ( $\quad$ ) Contrato terceirizado \\
\hline
\end{tabular}

Fonte: Dados da pesquisa. (2019).

Já sobre a indagação sobre a área responsável pela gestão das redes sociais, foi verificado que a TI - Tecnologia de Informação é responsável por esse monitoramento, aqui cabe uma importante informação/consideração, o setor de Marketing e Comunicação era para ter total acesso e acompanhamento disso, dado que é uma área estratégica para o relacionamento da IES, claro que a TI pode participar, com o monitoramento e análise dos dados coletados e observados, porém o papel do Marketing/ Comunicação é fundamental, talvez por isso que se tenha verificado sobre a não consideração em relação a esse item "Melhorar a comunicação da empresa" já discutido no Quadro 7.

Quadro 9: Principal objetivo/ expectativa dos clientes que aderem às redes sociais.

\begin{tabular}{|l|}
\hline $\begin{array}{l}\text { Qual o principal objetivo/expectativa dos clientes que aderem às } \\
\text { redes sociais da IES? }\end{array}$ \\
\hline $1^{\circ}$ lugar: Ser informado sobre as novidades \\
\hline $2^{\circ}$ lugar: Ser considerado cliente preferencial \\
\hline $3^{\circ}$ lugar: Conhecer as opiniões de outros consumidores \\
\hline $4^{\circ}$ lugar: Informar-se sobre promoções especiais \\
\hline
\end{tabular}

Fonte: Dados da pesquisa. (2019).

Sobre o objetivo dos alunos em aderirem às redes sociais da IES, foi verificado, segundo resposta do gestor, que o principal motivo é ser informado sobre as novidades, ficando em segundo lugar a questão de aderirem às redes para serem considerados clientes/ alunos especiais. Claro que entra a questão de conhecer as opiniões de outros consumidores/ alunos e por último a questão de informa-se sobre promoções especiais. Já que buscam em primeiro lugar novidades, volta-se a informar sobre a importância da melhoria da comunicação da IES com tal ferramenta de redes.

\section{Discussão}

Diante do questionário aplicado, os resultados obtidos confirmam a grande importância da utilização das redes sociais e suas ferramentas e benefícios, pois as ferramentas possibilitam a rápida troca de informações, a interatividade entre os clientes e funcionários e a facilidade do contato no ambiente interno da empresa. A entrevista buscou informações sobre a satisfação da IES na utilização das redes sociais, onde se observou a eficácia da ferramenta para contribuir com o desenvolvimento da empresa, aumentar a interatividades entre os seus clientes (alunos) e manter em seu banco de dados todos os contatos para troca de informações que possibilitam a proximidade entre a empresa e seus clientes.

A IES está cadastrada nas principais redes sociais, buscando a maior exposição na internet e confirma o grande sucesso do Facebook utilizando a rede social mais utilizada no mundo atualmente, com isso, a IES está buscando as vantagens em criar e propagar seus conteúdos que são de interesse de seu público-alvo, além disso, observou-se ainda à alta frequência de atualizações que permite a divulgação de forma dinâmica de tudo o que acontece na IES quase que em tempo real, com isso, as informações são muito bem absorvidas pelo público-alvo que recebem informações sobre notícias, novidades e comunicados, funcionários e colaboradores da IES que demonstram a intenção da melhora da relação empresa/clientes e empresa/fornecedores. 
A IES tem o Setor de TI como o responsável em alimentar, analisar, monitorar e verificar as ações nas redes sociais, observando as informações enviadas e recebidas para alunos que obtém um feedback positivo por ser mais um serviço oferecido aos alunos, funcionários e colaboradores, onde toda essa disponibilidade de informações propagadas de forma dinâmica na rede proporciona a credibilidade das informações que sempre estão disponíveis no site principal que está diretamente interligado com as redes sociais, onde toda a informação oficial é postada primeiramente no site e no mesmo momento as redes sociais recebem as informações, com tudo, a distribuição das informações ou a comunicação merece ser revisada, dado o que foi encontrado na pergunta referente ao Quadro 7.

\section{Considerações Finais}

A partir do presente trabalho podemos concluir que o marketing como as demais ações de uma empresa, bem como as demais ações com viés econômico teve em seu bojo um desenvolvimento histórico passando por diversas fases. Buscou-se de modo resumido, mas ainda assim bem claro, explicitar suas fases e explicar como atualmente ele tem uma importância fundamental nas chamadas mídias ou redes sociais.

A internet, como vimos, passou por diversas fazes e que uma série de estratégias econômicas e investimentos se deram em cada uma delas. Assim, foi possível perceber a migração de empresas que antes tinham apenas um espaço físico para uma dupla ação, ocupando também um espaço social, primeiramente em sites onde estes empreendiam diversas estratégias de marketing. A partir disso, entendemos que algumas das estratégias não obtiveram sucesso em virtude de falhas que também era percebida fora da internet. Buscando acompanhar este novo mercado empresas e marcas buscaram pesquisar e estudar o comportamento dos novos consumidores e assim empreender de modo mais exato seus investimentos.

Nos últimos anos quantias milionárias foram investidas em redes sociais através de grandes empresas e a velocidade onde se dão tais empreendimentos além de dados sobre as quantias investidas. Ficou também claro a possibilidade de novas empresas aderirem às redes sociais e como estas favorecem os investidores que tenham algumas estratégias que possam garantir aos seus clientes a qualidade de seus produtos e serviços bem como fidelizá-los por meio de uma interatividade cada vez maior, que é o que vem caracterizando tais relações.

Os clientes que agora tem um perfil bem diferente fazem do mercado das redes sociais um negócio dinâmico, exigente, mais aberto a quem ousar entendê-lo não mais como um consumidor distante, mas como um possível amigo, que além de um bom produto requer um atendimento diferenciado que entenda suas singularidades.

Observando e analisando os dados apresentados no presente trabalho percebemos que podemos confirmar o que em outros estudos já vinha sendo afirmado que é o notável desenvolvimento do e-commerce e como o mesmo é o resultado de uma nova dinâmica comercial resultante do processo de globalização. Esta por sua vez que tem a característica de sua difusão das mais diversas práticas culturais por todo o mundo nas últimas décadas tem se realizado agora em uma nova fase. Os investimentos agora não só são feitos em empreendimentos comerciais e/ou prestação de serviço em espaço físico com uma localização geográfica determinada, mas, sobretudo utilizando a possibilidade de sua expansão no mundo virtual, uma vez que neste podese fazer um uso do mesmo capital com maior possibilidade de retorno se bem investido.

$\mathrm{O}$ e-commerce aqui estudado com ênfase nas chamadas redes ou mídias sociais é, portanto, resultado de um longínquo processo de desenvolvimento comercial dos últimos anos e que antes de se configurar tal como o conhecemos hoje em dia, espalhou-se em redes pelo mundo. Tais redes, ainda que de modo bastante primitivo, buscavam maximizar o atendimento de empresas no maior espaço possível, com um centro organizador que demandava suas tarefas para todas as suas filiais. Não é preciso dizer que este processo demandava um grande custo operacional e financeiro e que por isso mesmo, na tentativa de superar tais dificuldades e evolução do capitalismo hoje se se explicita no meio virtual, sobretudo nas redes sociais, que abriram uma demanda muito grande no comercio eletrônico. 
Fica de sugestão para próximas pesquisas um estudo analisando a satisfação e utilização dos clientes, no caso os alunos, da referida IES em se tratando de redes sociais. Será que, na visão dos alunos, as redes sociais estão sendo bem trabalhadas por parte da IES? Tal questionamento torna-se relevante no intuito de descobrir a real satisfação dos alunos em relação à ferramenta.

O resultado aqui apresentado mostra que a utilização das redes sociais em IES, faz crescer a sua competitividade no mercado em função do seu posicionamento e também por melhor aproximação do seu publico alvo, desenvolvendo uma comunicação direta, clara e objetiva quanto a comunicação e informação dos seus produtos, serviços e propósito enquanto instituição para gerar identidade da mesma com os seu atuais e futuros clientes.

\section{Referências}

Adolpho, C. Os 8Ps do Marketing Digital. Editora Novatec.

Aristóteles (1999). La Política, Libro I. Madrid: Alba.

Cardozo, M. L. Propaganda Pessoal: Redes Sociais na Internet. USCS - Universidade Municipal de São Caetano do Sul, São Paulo, SP.

Castells, M. A Sociedade em Rede - A Era da Informação: Economia Sociedade e Cultura. São Paulo. Editora:Paz e Terra.

Castells, Comunicação Móvel e Sociedade. Editor:Fundação CalousteGulbenkian.

Castells, Conversas com Manuel Castells. Editora: Campo das Letras.

Chiavenato, I. Teoria Geral da Administração. Ed. Campus (2001)

Exame. Disponível em: http://exame.abril.com.br/marketing/noticias/6-marcas-que-estao-sacudindo-as-midias-sociais. http://exame.abril.com.br/marketing /noticias/6-marcas-que-estao-sacudindo-as-midias-sociais

Lefebvre, H. La production de l'espace. Paris: Anthropos.

M2brnet - Criatividade e Tecnologia. Disponível em: http://www.m2brnet.com/marketing_viral.php

Nanni, H. C., \& Cañete, K. V. S. A importância das Redes Sociais como Vantagem Competitiva nos Negócios Corporativos. VII Convibra Administração Congresso Virtual Brasileiro de Administração.

Qualman, E. Socialnomics - Como as Mídias Sociais Estão Transformando a forma como vivemos e fazemos negócios Editora Saraiva.

Qualman, E. Digital Leader: 5 Simple Keys to Success and Influence.

Santos, M. Economia espacial: críticas e alternativas. Hucitec.

Santos, M. Pensando o espaço do homem. Hucitec.

Santos, M. Por uma outra globalização - do pensamento único à consciência universal. Editora Record.

Shih, C. “The Facebook Era - Tapping Online Social Networks to Market, Sell, and Innovate. Editora Prentice Hall, (2a ed.), (Kindle Edition), EUA.

Sophia, M. Facebook - Por que curtir marcas e empresas. Disponível em: www.sophiamind.com/

Torres, C. Guia Prático de Marketing na Internet para Pequenas Empresas. 